\title{
Molecular Docking Studies on the Anti-viral Effects of Compounds From Kabasura Kudineer on SARS-CoV-2 3CL ${ }^{\text {pro }}$
}

OPEN ACCESS

Edited by:

Balakumar Chandrasekaran,

Philade/phia University, Jordan

Reviewed by:

Ding Lin,

Hunan University, China

Mohammad Shahid,

Children's National Hospital,

United States

*Correspondence:

Savariar Vincent

svincentloyola@gmail.com

Manoj Dhanraj

kmdmanoj@gmail.com

tThese authors have contributed equally to this work and share first

authorship

Specialty section:

This article was submitted to

Molecular Diagnostics and

Therapeutics,

a section of the journal

Frontiers in Molecular Biosciences

Received: 02 October 2020 Accepted: 27 November 2020 Published: 23 December 2020

Citation:

Vincent S, Arokiyaraj S, Saravanan M and Dhanraj M (2020) Molecular Docking Studies on the Anti-viral Effects of Compounds From Kabasura Kudineer on SARS-CoV-2 3CL pro.

Front. Mol. Biosci. 7:613401.

doi: 10.3389/fmolb.2020.613401

\author{
Savariar Vincent ${ }^{1 \star \dagger}$, Selvaraj Arokiyaraj ${ }^{2 \dagger}$, Muthupandian Saravanan ${ }^{3 \dagger}$ and Manoj Dhanraj ${ }^{1 *}$ \\ ${ }^{1}$ Centre for Environmental Research and Development (CERD), Loyola College, Loyola Institute of Frontier Energy, Chennai, \\ India, ${ }^{2}$ Department of Food Science and Biotechnology, Sejong University, Seoul, South Korea, ${ }^{3}$ Division of Biomedical \\ Science, Department of Medical Microbiology and Immunology, School of Medicine, College of Health Sciences, Mekelle \\ University, Mekelle, Ethiopia
}

The COVID-19 has now been declared a global pandemic by the World Health Organization. No approved drug is currently available; therefore, an urgent need has been developed for any antiviral therapy for COVID-19. Main protease $3 \mathrm{CL}^{\text {pro }}$ of this novel Coronavirus (SARS-CoV-2) play a critical role in the disease propagation, and hence represent a crucial target for the drug discovery. Herein, we have applied a bioinformatics approach for drug repurposing to identify the possible potent inhibitors of SARS-CoV-2 main proteases $3 C^{\text {pro }}$ (6LU7). In search of the anti-COVID-19 compound, we selected 145 phyto-compounds from Kabasura kudineer (KK), a poly-herbal formulation recommended by AYUSH for COVID-19 which are effective against fever, cough, sore throat, shortness of breath (similar to SARS-CoV2-like symptoms). The present study aims to identify molecules from natural products which may inhibit COVID-19 by acting on the main protease ( $\left.3 \mathrm{CL}^{\text {pro }}\right)$. Obtained results by molecular docking showed that Acetoside (-153.06), Luteolin 7 -rutinoside $(-134.6)$ rutin $(-133.06)$, Chebulagic acid (-124.3), Syrigaresinol (-120.03), Acanthoside (-122.21), Violanthin (-114.9), Andrographidine C (-101.8), myricetin (-99.96), Gingerenone -A (-93.9), Tinosporinone (-83.42), Geraniol (-62.87), Nootkatone (-62.4), Asarianin (-79.94), and Gamma sitosterol (-81.94) are main compounds from KK plants which may inhibit COVID-19 giving the better energy score compared to synthetic drugs. Based on the binding energy score, we suggest that these compounds can be tested against Coronavirus and used to develop effective antiviral drugs.

Keywords: COVID-19, molecular docking, Kabasura kudineer, iGemdock, anti-viral effects

\section{INTRODUCTION}

The World Health Organization has declared novel Coronavirus disease 2019 (COVID-19) to be a pandemic that went on to affect more than 219 countries with 44,002,003 confirmed cases and killed more than 1,167,988 people (WHO as of Oct 29, 2020) (Velavan and Meyer, 2020). The updated information is available on the WHO website (https:// www.who.int/emergencies/diseases/novel-coronavirus-2019). It has also ignited fears of an impending economic crisis and recession in the infected countries (Buck et al., 2020). In India, the first case was reported on January 30, 2020; as of Oct 29, 2020; 8,040,203 
cases have been confirmed by COVID-19 infection along with $7,032,000$ recoveries, 120,527 deaths with the fatality rate of 1.2\% (Ministry of Health and Family Welfare, India). On March 25, 2020, the Government of India announced a nationwide lockdown to cut the chain of community transmission. COVID19 is caused by Severe Acute Respiratory Syndrome Coronavirus 2 (SARS-CoV2) which results in respiratory illness among infected people. There are 7 Human Corona Virus (HCoV) strains identified so far and categorized into $\alpha-\mathrm{CoV}(229 \mathrm{E}$ and NL63) and $\beta-\mathrm{CoV}$ (OC43, HKU1, SARS, MERS, and COVID-19 $\mathrm{HCoVs}$ ). Among these, MERS HCoV and SARS were reported to be more virulent and have the highest mortality (Elfiky, 2020).

The $\mathrm{HCoV}$ is a positive sense virus with a single-stranded 30,000 bp RNA (+ssRNA). The virus consists of two clusters of proteins, namely (a) the non-structural RNA-dependent RNA polymerase (RRP) that is significant in the replication of the virus, and $3 \mathrm{C}$-Like Protease (3CL ${ }^{\text {pro }}$ ) enzyme that cleaves the two polyproteins (PP1A and PP1AB) translated from viral RNA in the host cell, and (b) Spike proteins that help in fusion and entry of the virus into the host, Nucleocapsid, Matrix and Envelope proteins (Elfiky et al., 2017).

The major symptoms include fever, cough, and breathing difficulties. So far, no vaccine is available, and no drugs have been found to cure the life-threatening coronavirus infection. But the research is continuing to identify the potent drug or vaccine. Only symptomatic relief is provided to the patients. Currently, antiviral drugs, MERS-Cov antibodies, SARS-CoV, and combination therapy of hydroxychloroquine and azithromycin are recommended (Gautret et al., 2020; Huang et al., 2020). These compounds prevent viral entry by inhibition of Angiotensin-Converting Enzyme 2 (ACE2) cellular receptor, acidification of cell membrane, and by immunostimulant activity. However, some reports show that the drug hydroxychloroquine is not effective for those infected with the coronavirus and shows adverse effects in patients with acute renal impairment (Pelle and Callen, 2002; Tailor et al., 2012).

Therefore, there is an urgent need to develop an alternative method to prevent novel SARS-CoV2 infection. Siddha medicine, an Indian medical system, uses specific polyherbal formulations for the treatment of infectious diseases (Zysk, 2009; Rajantheran et al., 2014).

Traditional methods of drug discovery could take years, whereas in silico-docking analysis enables large-scale screening fast, reliable, and cheaper than conventional drug development (Green and Segall, 2014). In silico analysis, we assess the binding ability of a ligand to protein at an active site as well as to compare the binding modes of different ligands to the active sitepocket (Leach, 2001). In this study, we used $3 \mathrm{CL}^{\text {pro }}$ as a possible targeting site to treat $\mathrm{HCoV}$. Previously the main protease (Mpro)/chymotrypsin-like protease (3CL ${ }^{\text {pro }}$ ) has been isolated through crystallization by Liu and Wang (2020) (PDB ID: 6LU7). The mechanism of $3 \mathrm{CL}^{\text {pro }}$ is deciphered computationally as the stearic interaction with glycine in the polyproteins and forms a strong hydrogen bonding to stabilize the complex. A conserved GSCGS motif has been observed to form three consecutive turns which were consequently temporarily stabilized by PNCC. This stabilizing PNCC is located on the surface opposite to the active

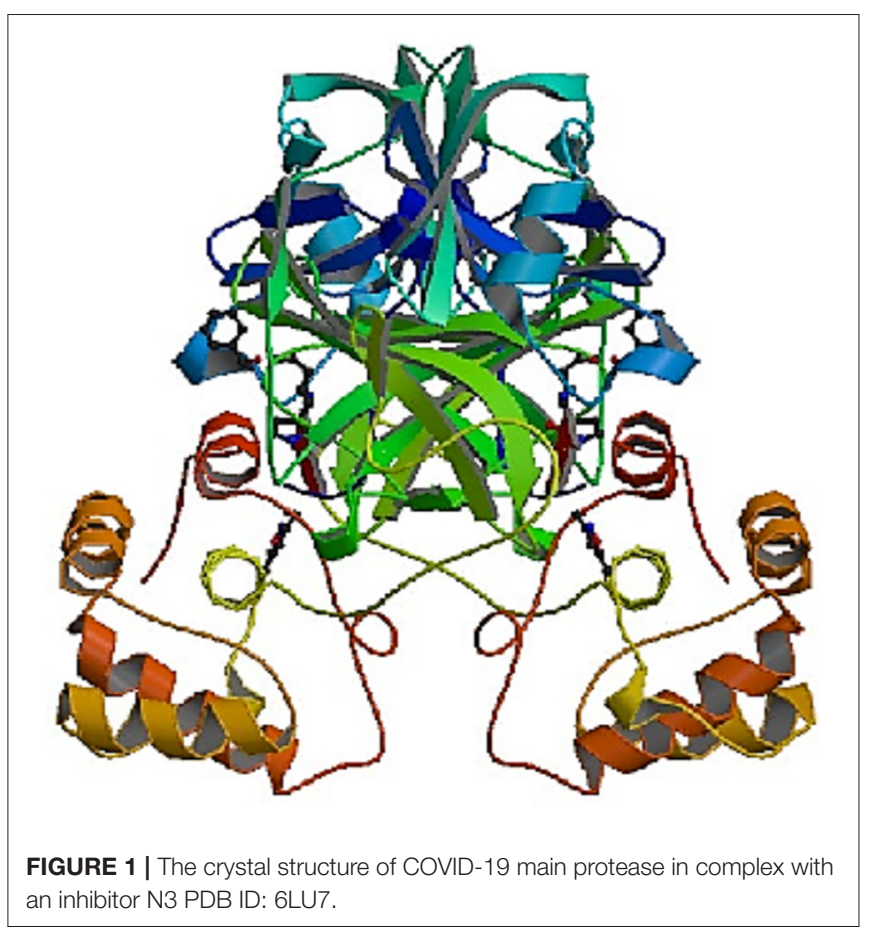

site and hence can be the potential drug targeting site for 3CL $\mathrm{C}^{\text {pro }}$ inhibitors (Wang et al., 2020).

In search of the anti-COVID-19 compound, we selected 145 phyto-compounds from Kabasura kudineer, a poly-herbal formulation prescribed in AYUSH for COVID-19 which are effective against flu, cough, sore throat, shortness of breath (similar to SARS-CoV2 like symptoms). [AYUSH Ministry of Health Corona Advisory-D.O. No. S. 16030/18/2019-NAM; 06th March 2020]. Therefore, the present study involves the analysis of 145 phytocompounds from Kabasura kudineer against the structure of SARS-CoV-2 3CL ${ }^{\text {pro }}$ through structure-based in silico molecular docking and to identify potent anti-COVID-19 natural compounds.

\section{MATERIALS AND METHODS}

In silico docking of the protein SARS-CoV-2 virus $3 \mathrm{CL}^{\text {pro }}$ (PDB ID: 6LU7), iGEMDOCK module software was used.

\section{Selection of Protein}

The 3CL ${ }^{\text {pro }}$ Mpro (PDB ID: 6LU7) protein structure COVID19 (Figure 1) containing the two chains (A\&B) was acquired from the protein data bank (www.rcsb.org). The PDB format extraction was used to study the crystal structure of the protein.

\section{Ligand Preparation}

We selected 145 phyto-compounds from Kabasura kudineer complex (Supplementary Table 1). A total of 145 twodimensional ligands were generated with ACD chem sketch. The ligands extracted in the mol format were converted to pdb format using OPEN BABEL software 
(www.vcclab.org/lab/babel/start.html). The docking tool iGEMDOCK v2.0 was used for the rapid virtual screening of the extracted compounds (Yang and Chen, 2004). Based on the highest energy value, best compounds from each plant of Kabasura kudineer complex were exposed to accurate molecular docking (Supplementary Table 2).

\section{Active Site Prediction}

The most significant step in molecular docking is to locate the ligand-binding sites on a protein. The protein-ligand binding sites are located using the novel energy-based method Q-Site Finder developed by Jackson, where the interaction energies of a methyl probe with a protein are analyzed (Laurie and Jackson, 2005). Using the software, the plausible active binding sites of toxins were obtained. The binding sites which are more flexible were preferred for this analysis.

\section{Protein-Ligand Docking}

After the compounds are screened, a virtual screening environment is created through an integrated tool iGEMDOCK. The tool affords the interactive interfaces to prepare both the binding site of the target protein and the screening compound library. Post-screening, each compound in the library is docked into the binding site and thereby generating the protein-compound interaction profiles of electrostatic, hydrogen-bonding, and van der Waals interactions. The tool then corroborates the pharmacological interactions and clusters the screening compounds for the post-screening analysis based on the interaction data and the compound structures, ranks and visualizes the screening compounds by combining the pharmacological interactions and energy-based scoring function. With the population size 800 set with 80 generation and 10 solutions, the ligands were subjected to very slow accurate docking and the docking pose and their corresponding energy values were analyzed.

\section{RESULTS AND DISCUSSION}

The present study focused on the main proteases $3 \mathrm{CL}^{\text {pro }} \mathrm{PDB}$ ID (6LU7), as potential target proteins for SARS - COVID19. Inhibition potential and effectiveness of compounds from Kabasura kudineer $(\mathrm{KK})$ against novel coronavirus $3 \mathrm{CL}^{\text {pro }}$ on molecular docking studies using Igemdock were investigated. The proteolytic maturation enzyme Mpro in CoV has been identified as the potential target protein to prevent the spread of infection through the inhibition of viral polyprotein cleavage (Liu and Wang, 2020). The discovery of the Mpro protease structure has facilitated the identification of potential drug candidates for treatment. The protein sequences of the two Coronavirus strains SARS-CoV Mpro and the 2019-nCoV Mpro are 96\% identical, and the active sites in both proteins remain free from mutations. In many viruses, proteases play essential roles in viral replication; therefore, proteases are often used as potential targets during the development of antiviral therapeutics (Chang et al., 2019). However, the disruption of protease activity in host cells can lead to various diseases. Hence, the host proteases can be generally used as potential therapeutic targets. Several compounds from medicinal plants have been reported to show antiviral properties (Thayil and Thyagarajan, 2016; Zakaryan et al., 2017; Jo et al., 2020). This study was conceived with a strategy of exploring the natural compounds which may impede the SARS-CoV-2 infection by blocking the viral entry into the host cell or inhibiting the viral polyprotein processing in the cell. In this context, KK comprises 15 individual herbs namely Andrographis paniculata, Syzygium aromaticum, Zingiber officinale, Tragia involuerta, Hygrophila auriculata, Terminaila chebula, Adhatoda vasica, Coleus ambonicus, Saussurea lappa, Clerodendrum serratum, Cypreus rotundus, Tinospora cordifolia, Sida acuta, Piper longum, and Anacyclus pyrethrum. Each plant consists of several compounds and exhibits various biological activities (Table 1).

From the documents of Dr. Lipinski, the molecules are categorized as the therapeutic compounds when they have sufficiently acceptable ADME properties (absorption, distribution, metabolism and excretion) and toxicity profiles to qualify through the Phase I clinical trial on humans. However, his postulate "rule of 5" classifies the molecules only based on the orally active drug phenomena that include molecular weight $\leq 500, \operatorname{cog} \mathrm{P} \leq 5, \mathrm{H}$ - bond donor $\leq 5$, and $\mathrm{H}$ - bond acceptor $\leq 10$. They do not evaluate the parameters of direct metabolism, frequency of the molecule or if it contains reactive functional groups.

In this present study, SARS-CoV-2 virus $3 \mathrm{CL}^{\text {pro }}$ was docked with 145 compounds selected from KK comprising plants. Ritonavir, Lopinavir, Oseltamivir, HCQ, Ivermectin, and Azithromycin are used as standard (Caly et al., 2020; Cao et al., 2020; Muralidharan et al., 2020). These ligands were screened based on their propensity to dock with the receptor molecule and to inhibit the protein activity. The extent of docking was ranked based on the iGEMDOCK scoring function to zero down the most accurate ligand. Eventually, during the virtual screening process, each compound from each plant that bound at different binding pockets of the $3 \mathrm{CL}^{\text {pro }}$ has been selected. Based on the highest energy value, best compounds from each plant of Kabasura kudineer complex were exposed to accurate molecular docking. Based on screening process, the highest-ranked compounds (Acetoside, Luteolin 7 -rutinoside, Rutin, Chebulagic acid, Acanthoside, Syrigaresinol, Violanthin, Andrographidine C, Myricetin, Gingerenone -A, Tinosporinone, Geraniol, Nootkatone, Asarianin, and Gamma sitosterol) were selected for accurate docking against SARS$\mathrm{CoV}-2$ virus $3 \mathrm{CL}^{\text {pro }}$ and their corresponding energy values are listed in Table 2 (Structure of target compounds are shown in Supplementary Figure 1). The energy values are inversely proportional to the acceptability of the molecule as a drug. Molecules that scored best by iGEMDOCK scoring functions were identified as potential leads for COVID-19 drug discovery process.

Table 2 shows the energy value, binding domain and amino acids found in the active site pockets of 6LU7 against compounds from KK. The Acetoside from Clerodendrum serratum docked with the $3 \mathrm{CL}^{\text {pro }}$ and the total fitness value was found to be $-153.06 \mathrm{kcal} / \mathrm{mol}$, which comprises of -93.6 van der Waal interactions and $-59.46 \mathrm{kcal} / \mathrm{mol}$ hydrogen bonding 
TABLE 1 | List of plants included in Kabasura kudineer, a poly herbal formulation as recommend by AYUSH.

\begin{tabular}{|c|c|c|c|}
\hline S. No & Medicinal plants & Pharmacological properties & References \\
\hline 1 & Andrographis paniculata & $\begin{array}{l}\text { Anti-viral, anti-cancer, anti-inflammatory, angiogenic, anti-venom, anti-diabetic, and } \\
\text { anti-malarial properties }\end{array}$ & $\begin{array}{l}\text { Bharati et al., 2011; Hossain et al., } \\
2014\end{array}$ \\
\hline 2 & Syzygium aromaticum & $\begin{array}{l}\text { Anti-bacterial, anti-fungal, insecticidal, analgesic, anti-spasmodic, anti-carminative, } \\
\text { and anti-oxidant properties }\end{array}$ & $\begin{array}{l}\text { Jimoh et al., 2017; Kaur and Kaushal, } \\
\text { 2019; Batiha et al., } 2020\end{array}$ \\
\hline 3 & Zinigiber officianle & $\begin{array}{l}\text { Anti-emetic, anti-oxidant, anti-diabetic, anti-pyretic, analgesic, anti-arthritic, and } \\
\text { anti-inflammatory activities }\end{array}$ & $\begin{array}{l}\text { Amir et al., 2011; Rahmani, 2014; } \\
\text { Marrelli et al., } 2015\end{array}$ \\
\hline 4 & Tragia involucrata & $\begin{array}{l}\text { Anti-microbial, analgesic, anti-epileptic, anti-diabetic, anthelmintic, anti-inflammatory, } \\
\text { anti-fertility, anti-diuretic, anti-pyretic, anti-oxidant, and cytotoxic activities }\end{array}$ & $\begin{array}{l}\text { Dhara et al., 2000; Rao et al., 2007; } \\
\text { Mothana et al., 2010; Gobalakrishnan } \\
\text { et al., } 2013\end{array}$ \\
\hline 5 & Hygrophila auriculata & $\begin{array}{l}\text { Anti-cancer, hypoglycemic, aphrodisiac, anti-microbial, anti-oxidant, lipid } \\
\text { peroxidation, hepatoprotective, and hematopoietic activity }\end{array}$ & $\begin{array}{l}\text { Hussain et al., 2010; Salve and } \\
\text { Bhuktar, } 2017\end{array}$ \\
\hline 6 & Terminalia chebula & $\begin{array}{l}\text { Anti-bacterial, anti-microbial, anti-fungal, anti-viral, anti-oxidant, anti-ulcer, and } \\
\text { anti-helmintic }\end{array}$ & $\begin{array}{l}\text { Ashwini et al., 2011; Rathinamoorthy } \\
\text { and Thilagavathi, 2014; Upadhyay } \\
\text { et al., } 2014\end{array}$ \\
\hline 7 & Adhatoda vasica & $\begin{array}{l}\text { Anti-asthmatic and bronchodilator activity, wound healing activity, anti-ulcer activity, } \\
\text { cholagogue activity, anti-allergy activity, anti-tubercular activity, abortifacient and } \\
\text { uterotonic activity, insecticidal activity, and anti-bacterial activity }\end{array}$ & $\begin{array}{l}\text { Singh et al., 2011; Gangwar and } \\
\text { Ghosh, 2014; Kumar et al., } 2014\end{array}$ \\
\hline 8 & Coelus amboinicus & Urolithiasis, fungitoxic, anti-bacterial, anti-malarial, and anti-inflammatory & $\begin{array}{l}\text { Pillai et al., 2011; Rout et al., 2012; } \\
\text { Arumugam et al., } 2016\end{array}$ \\
\hline 9 & Saussurea lappa & $\begin{array}{l}\text { Anti-arthritic, anti-convulsant, anti-cancer, anti-inflammatory, anti-larvicidal, anti-ulcer, } \\
\text { anti-viral, and hepatoprotective activities }\end{array}$ & $\begin{array}{l}\text { Liu et al., 2012; Madhuri et al., 2012; } \\
\text { Singh et al., } 2017\end{array}$ \\
\hline 10 & Clerodendrum serratum & $\begin{array}{l}\text { Anti-oxidant, anti-bacterial, anti- carcinogenic, hepatoprotective, wound healing, and } \\
\text { anti-allergic properties }\end{array}$ & $\begin{array}{l}\text { Patel et al., 2014; Noreen et al., 2018; } \\
\text { Mahajan et al., } 2019\end{array}$ \\
\hline 11 & Cyperus rotundus & $\begin{array}{l}\text { Anti-androgenic, anti-mutagenic, anti-obesity, anti-oxidant, anti-uropathogenic, } \\
\text { anti-diarrheal, anti-genotoxic, anti-cancerous, anti-convulsant, anti-diabetic, } \\
\text { anti-bacterial, anti-lipidemic, antimalarial, anti-inflammatory, hepatoprotective, } \\
\text { cardioprotective, and neuroprotective }\end{array}$ & Peerzada et al., 2015; Al-Snafi, 2016 \\
\hline 12 & Tinospora cordifolia & $\begin{array}{l}\text { Anti-cancer, anti-diabetes, anti-viral, anti-inflammatory, anti-psychiatric, and } \\
\text { immunomodulatory action }\end{array}$ & $\begin{array}{l}\text { Rout, 2006; Patel et al., 2009; } \\
\text { Upadhyay et al., 2010; Gupta and } \\
\text { Sharma, 2011; Tiwari et al., } 2018\end{array}$ \\
\hline 13 & Sida acuta & $\begin{array}{l}\text { Anti-plasmodial, anti-ulcer, hypoglycemic, anti-bacterial, anti-fungal, anti-oxidant, } \\
\text { anti-inflammatory, analgesic, anti-pyretic, hepatoprotective, and cytotoxic activities }\end{array}$ & $\begin{array}{l}\text { Karou et al., 2017; Jindal et al., 2012; } \\
\text { Tcheghebe et al., } 2017\end{array}$ \\
\hline 14 & Piper longum & $\begin{array}{l}\text { Anti-cancer, anti-oxidant, anti-inflammatory, anti-microbial, anti-hyperlipidemic, } \\
\text { anti-obesity, and analgesic activities }\end{array}$ & Zaveri et al., 2010; Kumar et al., 2011 \\
\hline 15 & Anacyclus pyrethrum & $\begin{array}{l}\text { Anti-rheumatic, analgesic, anti-bacterial, anti-diabetic, anti-oxidant, anti-inflammatory, } \\
\text { and anti-nociceptive activities }\end{array}$ & Selles et al., 2013; Usmani et al., 2016 \\
\hline
\end{tabular}

Ref: AYUSH Ministry of Health Corona Advisory -D.O. No. S. 16030/18/2019-NAM; dated: O6th March, 2020.

interactions. The inhibitor closely fits the active site cavity making various close contacts with the residues including hydrogen bonding with the main chain of arginine at position 131 with binding energy value $-9.3 \mathrm{kcal} / \mathrm{mol}$ (Figure 2A). Acteoside, a phenylethanoid glycoside, is an active compound in several plants and traditional herbal medicines (Kubica et al., 2017). The study reports that the acetoside having the highest binding energy is very effective to inhibit the $3 \mathrm{CL}^{\text {pro. }}$ Similarly, Song et al. (2016) reported that the acetoside inhibits viral infections in a dose-dependent manner. The interactions and fitness score of the compound suggest that these leads can be formulated as an anti-COVID drug.

Luteolin 7- rutinoside from Hygrophila auricualata docked with $3 \mathrm{CL}^{\text {pro }}$ exhibits the energy value $-134.6 \mathrm{kcal} / \mathrm{mol}$, which comprises of -98.9 van der Waal interaction and -36.23 $\mathrm{kcal} / \mathrm{mol}$ hydrogen bonding interactions (Figure 2B). Here, the main chain Leucine at position 287 with binding energy is $-11.8 \mathrm{kcal} / \mathrm{mol}$. It was predicted that the hydroxyl ($\mathrm{OH})$, ketone $(=\mathrm{O})$, and ether $(-\mathrm{O}-)$ groups in luteolin compounds majorly impact the amino acid residue interactions at the active site of COVID-19 Mpro (Aziz et al., 2018). Luteolin derivatives have been predicted to interact with the NS2/NS3 protease used in silico analysis showed that luteolin reduces DENV infection through the inhibition of human furin, which is an enzyme involved in the maturation of the virions (Ramana et al., 2015; Dwivedi et al., 2016). It is apparent from the study, that Luteolin 7- the 3CL protease.

Rutin from Tragia involerta docked with $3 \mathrm{CL}^{\text {pro }}$ exhibits the energy value is $-133.06 \mathrm{kcal} / \mathrm{mol}$, which comprises of -85.08 van der Waal interaction and $-47.99 \mathrm{kcal} / \mathrm{mol}$ hydrogen bonding interactions (Figure 2C). Here, the main chain is arginine with $\mathrm{H}-\mathrm{S}$ domain at the position 131 with binding energy $-11.8 \mathrm{kcal} / \mathrm{mol}$. Jasso-Miranda et al. (2019) and Zandi et al. 
TABLE 2 | Accurate Molecular Docking studies on the target Phytocompounds from Kabasura kudineer (KK) with 3CL pro (6LU7) of the SARS-CoV2 Coronavirus using iGEMDOCK software.

\begin{tabular}{|c|c|c|c|c|c|c|c|c|}
\hline S. no & Name of the plant & Compound name & Molecular formula and weight & Energy & VDW & $\mathrm{H}$ bond & Binding domain & Aminoacid \\
\hline 2 & Hygrophila auricualata & $\begin{array}{l}\text { Luteolin } 7 \text {-rutinoside } \\
\text { (S. Figure 1b) }\end{array}$ & $\begin{array}{l}\mathrm{C}_{27} \mathrm{H}_{30} \mathrm{O}_{15} \\
594.5 \mathrm{~g} / \mathrm{mol}\end{array}$ & -134.6 & -98.39 & -36.23 & $\begin{array}{l}H-S \\
H-M \\
\text { V-M* } \\
\text { V-S }\end{array}$ & $\begin{array}{l}\text { ARG-131 } \\
\text { THR-199 } \\
\text { ASN-238 } \\
\text { LEU-287 } \\
\text { ASP-289 } \\
\text { THR-199 } \\
\text { TYR-239 } \\
\text { LEU-286 } \\
\text { LEU-287 } \\
\text { ASP-289 }\end{array}$ \\
\hline 3 & Tragia involerta & $\begin{array}{l}\text { Rutin } \\
\text { (S. Figure 1c) }\end{array}$ & $\begin{array}{l}\mathrm{C}_{27} \mathrm{H}_{30} \mathrm{O}_{16} \\
610.5 \mathrm{~g} / \mathrm{mol}\end{array}$ & -133.06 & -85.08 & -47.99 & $\begin{array}{l}\text { H-S } \\
\text { H-M } \\
\text { V-M } \\
\text { V-S }\end{array}$ & $\begin{array}{l}\text { ARG-131 } \\
\text { THR-199 } \\
\text { LEU-287 } \\
\text { THR-199 } \\
\text { TYR-239 } \\
\text { LEU-286 } \\
\text { LEU-287 } \\
\text { ASP-289 }\end{array}$ \\
\hline 4 & Terminalia chebula & $\begin{array}{l}\text { Chebulagic acid } \\
\text { (S. Figure 1d) }\end{array}$ & $\begin{array}{l}\mathrm{C}_{41} \mathrm{H}_{30} \mathrm{O}_{27} \\
954.7 \mathrm{~g} / \mathrm{mol}\end{array}$ & -124.3 & -103.2 & -21.28 & $\begin{array}{l}\text { H-S } \\
\text { H-M } \\
\text { V-M } \\
\text { V-S* }^{*}\end{array}$ & $\begin{array}{l}\text { THR-199 } \\
\text { LEU-287 } \\
\text { ASP-289 } \\
\text { THR-199 } \\
\text { TYR-239 } \\
\text { LEU-286 } \\
\text { LEU-287 } \\
\text { ASP-289 }\end{array}$ \\
\hline 6 & Sausurea lappa & $\begin{array}{l}\text { Syrigaresinol } \\
\text { (S. Figure 1e) }\end{array}$ & $\begin{array}{l}\mathrm{C}_{28} \mathrm{H}_{36} \mathrm{O}_{13} \\
580.6 \mathrm{~g} / \mathrm{mol}\end{array}$ & -120.03 & -79.99 & -40.04 & $\begin{array}{l}\mathrm{H}-\mathrm{S}^{*} \\
\mathrm{~V}-\mathrm{S}\end{array}$ & $\begin{array}{l}\text { ASN-151 } \\
\text { GLU-240 } \\
\text { THR-292 } \\
\text { GLY-110 }\end{array}$ \\
\hline 7 & Adhatoda vasica & $\begin{array}{l}\text { Violanthin } \\
\text { (S. Figure 1g) }\end{array}$ & $\begin{array}{l}\mathrm{C}_{27} \mathrm{H}_{30} \mathrm{O}_{14} \\
578.5 \mathrm{~g} / \mathrm{mol}\end{array}$ & -114.9 & -76.13 & -38.81 & $\begin{array}{l}\mathrm{H}-\mathrm{M} \\
\mathbf{H}-\mathbf{S}^{*} \\
\mathrm{~V}-\mathrm{M}\end{array}$ & $\begin{array}{l}\text { PHE-219 } \\
\text { ASN-221 } \\
\text { LEU-271 } \\
\text { ARG-279 } \\
\text { LEU-220 }\end{array}$ \\
\hline 8 & Andrographis paniculata & $\begin{array}{l}\text { Andrographidine C } \\
\text { (S. Figure } 1 \mathrm{~h} \text { ) }\end{array}$ & $\begin{array}{l}\mathrm{C}_{23} \mathrm{H}_{24} \mathrm{O}_{10} \\
460.4 \mathrm{~g} / \mathrm{mol}\end{array}$ & -101.8 & -72.41 & -29.36 & $\begin{array}{l}\text { H-S } \\
\text { H-M } \\
\text { V-M* } \\
\text { V-S }\end{array}$ & $\begin{array}{l}\text { ARG-131 } \\
\text { THR-199 } \\
\text { ASN-238 } \\
\text { ASP-289 } \\
\text { THR-199 } \\
\text { TYR-239 } \\
\text { LEU-286 } \\
\text { LEU-287 } \\
\text { ASP-289 }\end{array}$ \\
\hline
\end{tabular}


TABLE 2 | Continued

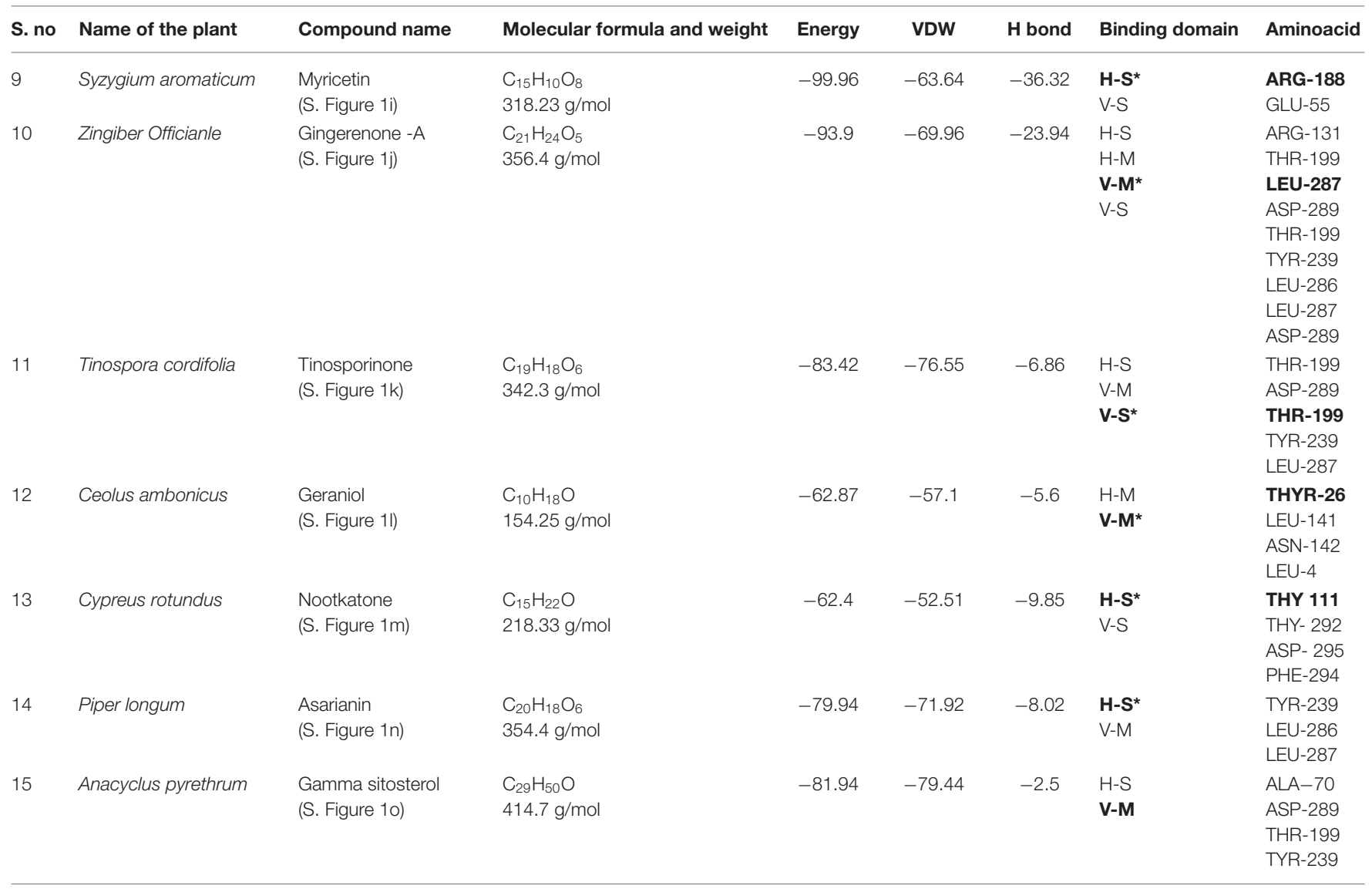

*The possible binding modes of selected phytochemicals at the target protein active sites.

H-S signifies hydrogen bond with sidechain.

$H$-M signifies hydrogen bond with the main chain.

$V$-M signifies Vander waals interaction with main chain.

$V$-S signifies Vander waals interaction with side chain.

S. Figure - Supplementary Figure 1 (a-o).

Bold values indicates the best interaction of amino acids along with hydrogen bond, side chain, main chain, and vander walls.

(2011) studied the antiviral activity of Rutin against Dengue virus type-2.

Chebulagic acid from Terminalia chebula docked with 3CL ${ }^{\text {pro }}$ exhibits the energy value of $-124.3 \mathrm{kcal} / \mathrm{mol}$, which comprises of -103.02 van der Waal interaction and $-21.28 \mathrm{kcal} / \mathrm{mol}$ hydrogen bonding interactions (Figure 2D). The inhibitor closely fits the active site cavity making various close contacts with the residues including hydrogen bonding with the main chain of Thyronine at position 239 with binding energy value $-17.9 \mathrm{kcal} / \mathrm{mol}$. Li et al. (2020) observed chebulagic acid as Novel Influenza Viral Neuraminidase Inhibitor. Similarly, Lin et al. (2013) also observed the chebulagic acid blocked herpes simplex virus type 1 (HSV-1).

Acanthoside isolated from Sida acuta possesses the energy value $-122.21 \mathrm{kcal} / \mathrm{mol}$, which contains the -79.44 van der Waal interaction and $-42.5 \mathrm{kcal} / \mathrm{mol}$ hydrogen bonding interactions (Figure 3B). Arginine 131 is the major active site to bind with receptors and the domain of H-S. Sida genus possesses various biological activities, especially anti-viral properties. No anti-viral reports have been reported from Acanthoside from Sida acuta.

Docking value of Syrigaresinol (Figure 3A) from Sausurea lappa exhibits $-120.03 \mathrm{kcal} / \mathrm{mol}$, Violanthin from Adhatoda vasica exhibits $-114.9 \mathrm{kcal} / \mathrm{mol}$ on $3 \mathrm{CL}^{\text {pro }}$ which comprises of -79.99 and -76.13 van der Waal interactions and -40.04 and $-38.81 \mathrm{kcal} / \mathrm{mol}$ hydrogen bonding interactions (Figure 3C). The residues include hydrogen bonding with the main chain of Glucine at position 240 with binding energy value $-7.6 \mathrm{kcal} / \mathrm{mol}$ in Syrigaresinol and Leucine at position 271 with binding energy value $-8.2 \mathrm{kcal} / \mathrm{mol}$ in Violanthin respectively. Likewise, Ouyang et al. (2007) also studied the Syringaresinol lignan inhibiting the multiplication of the tobacco mosaic virus. No study has been reported on violanthin, but this plant exhibits various pharmacological activities. It is evident from the study both the compounds effectively inhibited the 3CL protease.

Andrographidine C from Andrographis paniculata docked with $3 \mathrm{CL}^{\text {pro }}$ exhibits the energy value of $-101.8 \mathrm{kcal} / \mathrm{mol}$, which comprises of -72.41 van der Waal interactions and 29.36 


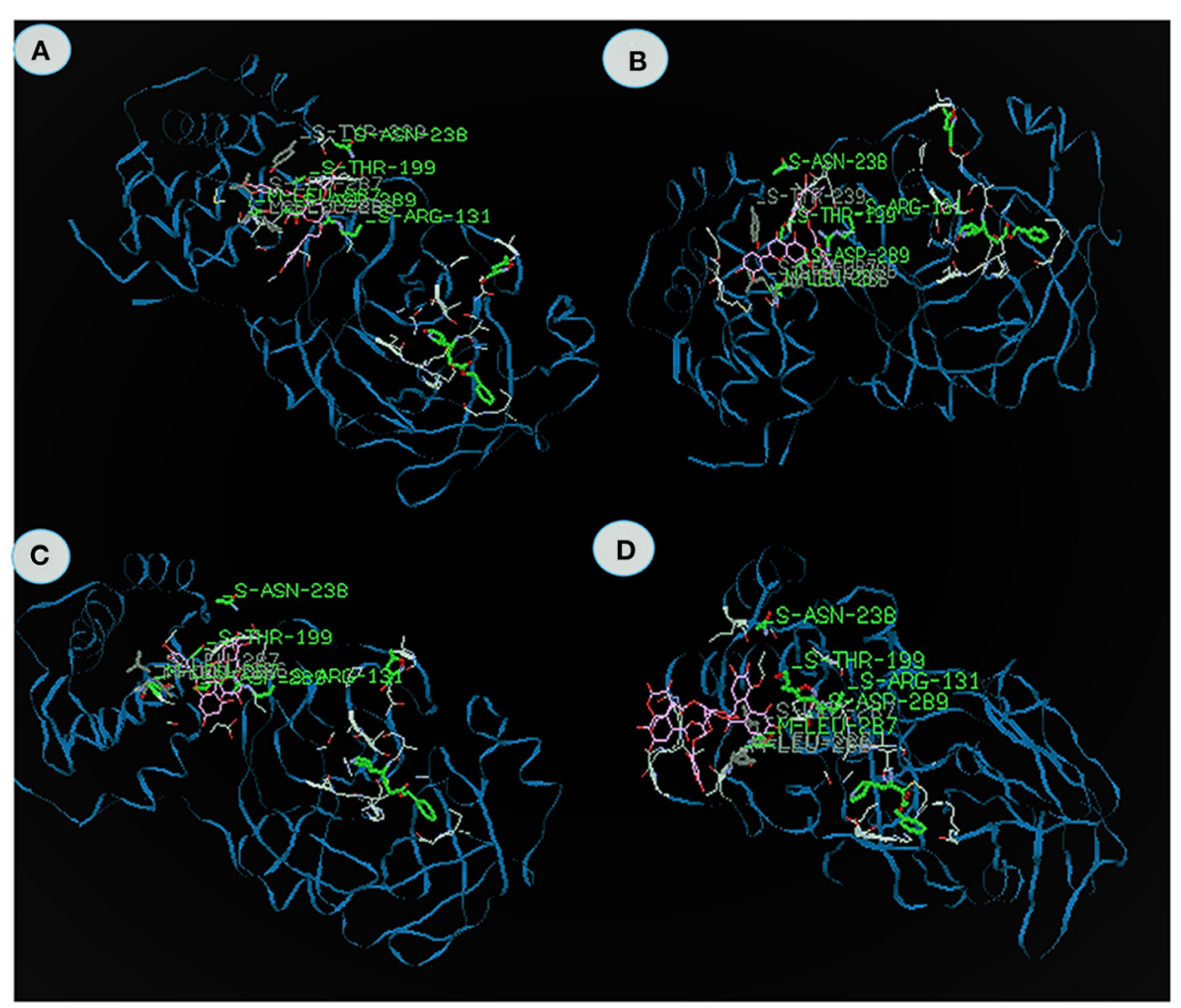

FIGURE 2 | The binding affinities of target compounds (A) Acetoside, (B) Luteolin 7 -rutinoside (C) rutin (D) Chebulagic acid present in the Kabasura kudineer (KK) with $3 \mathrm{CL}^{\text {pro }}$ (6LU7) of the SARS-CoV2 Coronavirus.

$\mathrm{kcal} / \mathrm{mol}$ hydrogen bonding interactions (Figure 3D). Here, the main chain and the amino acid region is leucine with $\mathrm{V}-\mathrm{M}$ domain at the position 286 with binding energy $-8.3 \mathrm{kcal} / \mathrm{mol}$. Wiart et al. (2005) reported Antiviral properties of ent-labdene diterpenes of Andrographis paniculata Nees, inhibitors of herpes simplex virus type 1. Similarly, Sharma et al. (2019) also studied that the Green synthesis of silver nanoparticles from Andrographis paniculata exhibits the antiviral potential against chikungunya virus.

Docking value of Myricetin from Syzygium aromaticum exhibits $-99.96 \mathrm{kcal} / \mathrm{mol}$ and Gingerenone from Zingiber officinale exhibits $-93.9 \mathrm{kcal} / \mathrm{mol}$ which comprises of -63.64 and -69.96 van der Waal interactions and -36.32 and -23.94 $\mathrm{kcal} / \mathrm{mol}$ hydrogen bonding interactions (Figures $4 \mathbf{A}, \mathbf{B}$ ). The residues include hydrogen bonding with the main chain of Arginine at position 188 with binding energy value -5.2 $\mathrm{kcal} / \mathrm{mol}$ in Myricetin and Leucine at position 287 with binding energy value $-5.4 \mathrm{kcal} / \mathrm{mol}$ in Gingerenone respectively. Park et al. (2013) and Ortega et al. (2017) opined that myricetin exhibits antiviral activity against influenza viruses and anti-HIV1 activity. It is clear from the above study that myricetin exhibits anti-viral properties against COVID-19. Likewise, Gingerenone A, a polyphenol present in ginger, has attracted increasing attention as potential agents for preventing and treating many oxidative stress-related diseases. No anti-viral report has been published on this compound, but Zingiber officianle possessed excellent anti-viral properties (Sharma et al., 2015; Kaushik et al., 2020).

Tinosporinone from Tinospora cordifolia exhibits the energy value $-83.42 \mathrm{kcal} / \mathrm{mol}$, which contains the -76.55 van der Waal interaction and $-6.86 \mathrm{kcal} / \mathrm{mol}$ hydrogen bonding interactions (Figure 4C). The inhibitor closely binds with the specific active site making various close contacts with the residues including hydrogen bonding with the main chain of Thyronine at position 199 with binding energy value $-7.2 \mathrm{kcal} / \mathrm{mol}$. Sharma et al. (2019) reported that the Tinospora cordifolia exhibits potential antiviral properties against chikungunya virus. Synergetic effects of these compounds possess excellent anti-viral properties against viral diseases.

Geraniol from Ceolus ambonicus (Figure 4D) and Nootkatone (Figure 5A) from Cypreus rotundus exhibit the energy value -62.87 and $-62.4 \mathrm{kcal} / \mathrm{mol}$ which contain the -57.1 and -52.51 van der Waal interactions and -5.6 and $-9.8 \mathrm{kcal} / \mathrm{mol}$ hydrogen bonding interactions. Lowest binding energy was observed in these two plants. Thyronine 26 and thyronine 111 are the major active sites to bind with 3CL ${ }^{\text {pro }}$. Mileva et al. (2015) reported the antiviral properties of Geraniol. Any specific anti-viral report on Nootkatone was not published and it is evident from the investigation that we can use Nootakatone as anti-viral agent for future purposes.

Asarianin (Figure 5B) isolated from Piper longum and Gamma sitosterol from Anacyclus pyrethrum (Figure 5C) 


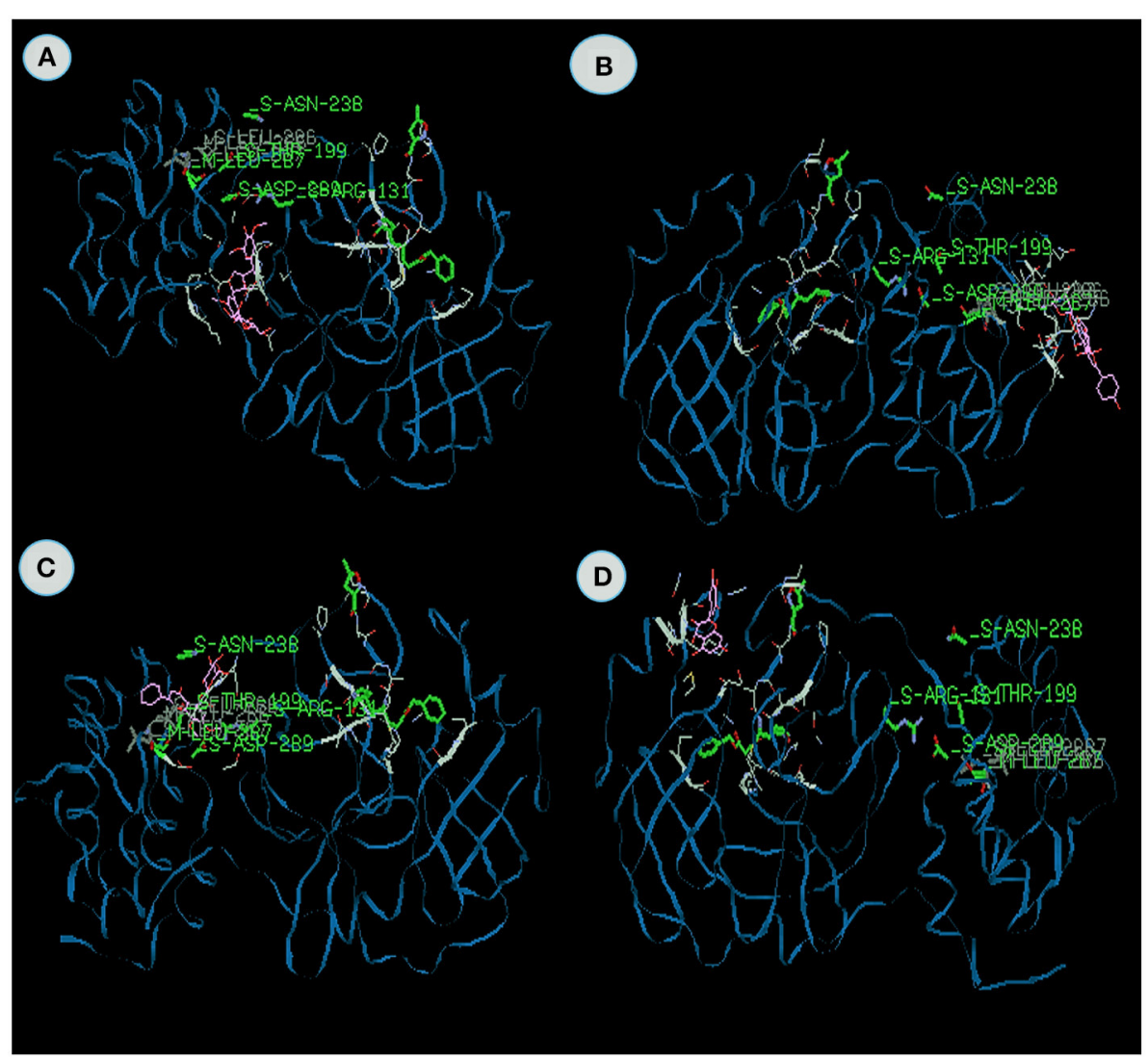

FIGURE 3 | The binding affinities of target compounds (A) Syrigaresinol (B) Acanthoside (C) Violanthin (D) Andrographidine C present in the Kabasura kudineer (KK) with $3 \mathrm{CL}^{\text {pro }}(6 \mathrm{LU} 7)$ of the SARS-CoV2 Coronavirus.

exhibits excellent binding energy against 3CL proviruses and it was found to be -79.94 and $-81.94 \mathrm{kcal} / \mathrm{mol}$ which comprises of van der Waal interaction and hydrogen bonding interactions. The main active site and domain range of the Asarianin are Thyronine 239 and H-S. Likewise, Alanine 70 and $\mathrm{V}-\mathrm{M}$ are the active site and binding domain of the $3 \mathrm{CL}^{\text {pro }}$ on Gammasitosterol. Mair et al. (2016) reported the antiviral activity of piperamides from black pepper. It is the first report that Anacyclus pyrethrum possesses antiviral properties on $3 \mathrm{CL}^{\text {pro }}$ by using in silico analysis.

The analysis reports of docking inclusive of the $\mathrm{H}$-bonds that interact with 6LU7 amino acids are tabulated in Table 2. It was observed that every $\mathrm{H}$-bond interacted with the amino acids in the COVID-19 Mpro active site. The presence of $\mathrm{H}$-bonds formed further influences the binding energy. The active site is usually pivotal in analyzing whether the binding site of the ligands has interacted with the amino acids of the target or attached to any other site inside the target. In the present research, the molecular docking analysis affirmed that all the ligands from the natural compounds interacted with the active site of the target protease. The nature and amount of bonding with the active site of the protein decides the higher affinity of drug compounds. Based on the binding energy score, we suggest that Acetoside, Luteolin 7 -rutinoside, rutin, Chebulagic acid, Syrigaresinol, Acanthoside, Violanthin, Andrographidine C, and myricetin exhibit excellent anti-viral properties when compared to synthetic drugs.

Based on the binding energy score, we suggest that these compounds can be tested against Coronavirus and used to develop effective antiviral drugs. Recently, plant compounds such as flavonoids showed good docking affinity against SARS-CoV-2 3CLpro (Jo et al., 2020) and there are several reports on Indian medicinal plants used to treat SARS-CoV infections. In line with this, Andrographis paniculata was reported to suppress NLR Family Pyrin Domain Containing 3, caspase-1 and IL-1 $\beta$ activity on SARS-CoV and likely SARS-CoV-2 virus (Liu et al., 2020a, Liu et al., 2020b). Glycyrrhizin active compound from Glycyrrhiza glabra inhibits viral replication of the SARS-associated virus (Cinatl et al., 2003). In addition to their ability to interfere with viral replication, andrographolide from Andrographis paniculata exhibits anticancer and immunostimulatory effects (Kumar et al., 2004). Similarly, Jain et al. (2020) reported that the polyherbal formulation of Nilavembu Kudineer has a prophylactic effect and antiviral effect against chikungunya and dengue virus infection. 


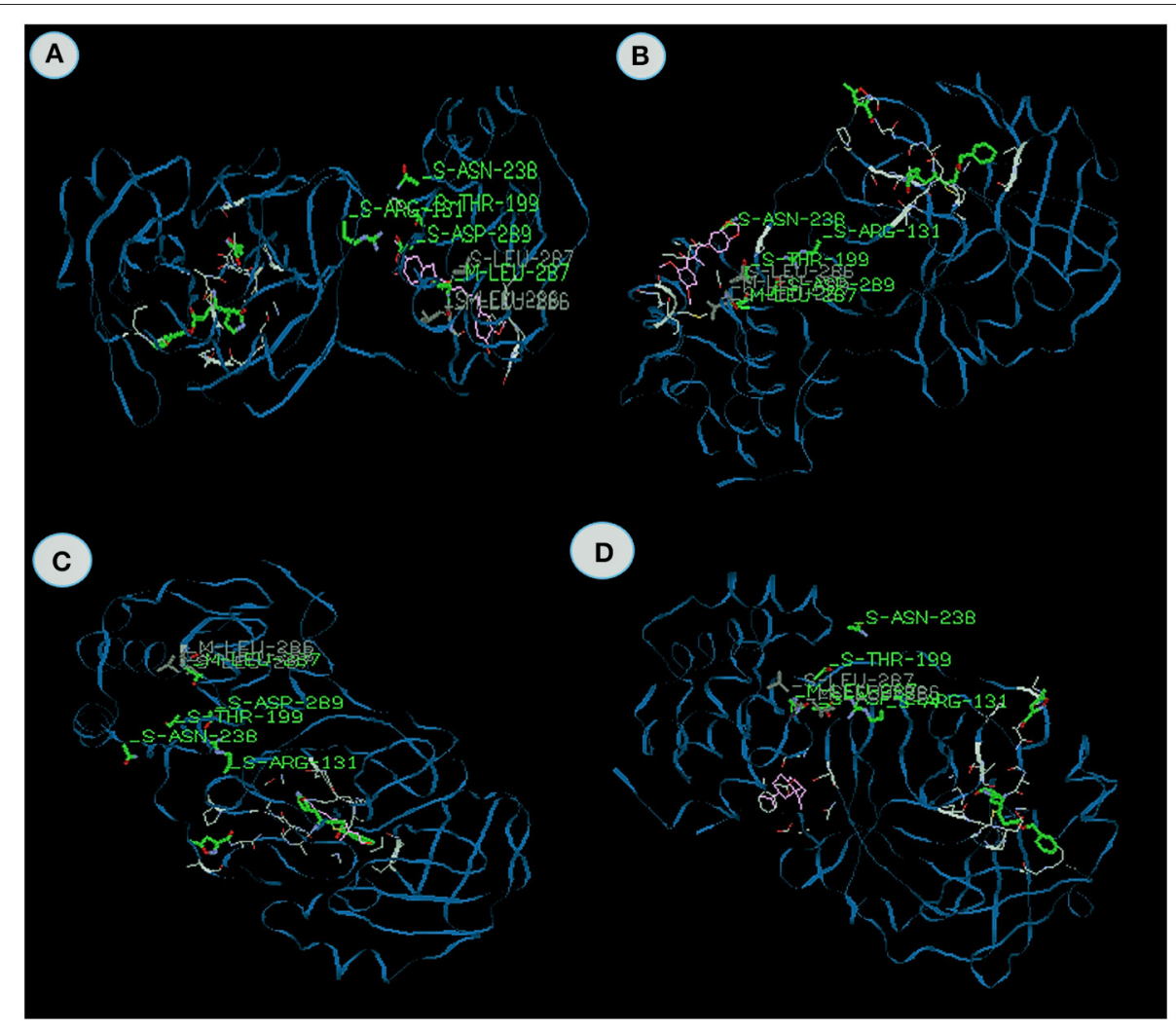

FIGURE 4 | The binding affinities of target compounds (A) myricetin (B) Gingerenone -A, (C) Tinosporinone, (D) Geraniol present in the Kabasura kudineer (KK) with $3 \mathrm{CL}^{\text {pro }}$ (6LU7) of the SARS-CoV2 Coronavirus.

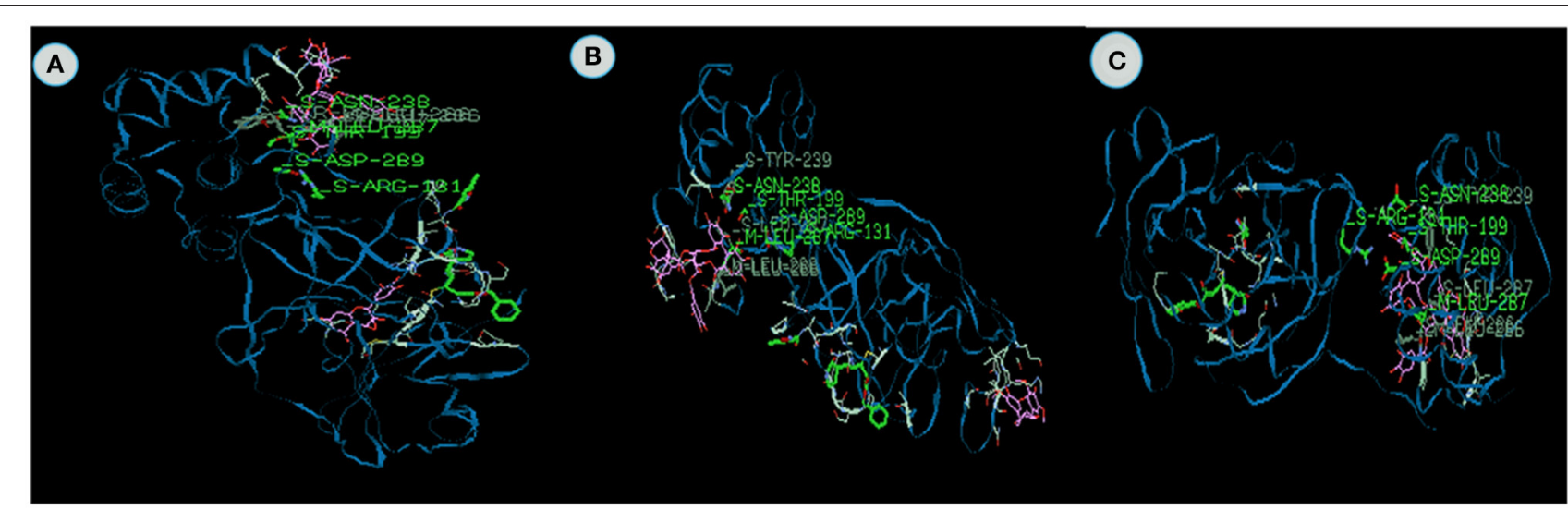

FIGURE 5 | The binding affinities of target compounds (A) Nootkatone (B) Asarianin and (C) gamma- sitosterol present in the Kabasura kudineer (KK) with $3 C L^{\text {pro }}$ (6LU7) of the SARS-CoV2 Coronavirus.

This study hypothesizes that a group of compounds from KK may exert its antiviral properties against novel coronavirus SARS$\mathrm{CoV}-2$ by either blocking the host cell receptor or inhibiting the key viral protease required for its replication in the host cell. This study might render light on the drug discovery studies for the treatment of viral infections similar to SARS or COVID-19 in future.

\section{CONCLUSION}

The possible medications using natural compounds were screened from approved bioactive compound databases using molecular docking techniques. This research was aimed at identifying the molecules from natural products that could effectively inhibit the COVID-19 by acting on the main protease 
(Mpro). Obtained results from molecular docking showed that Acetoside, Luteolin 7 -rutinoside, rutin, Chebulagic acid, Syrigaresinol, Acanthoside, Violanthin, Andrographidine C, myricetin, Gingerenone -A, Tinosporinone, Geraniol, Nootkatone, Asarianin, and sitosterol are main compounds from KK plants which may inhibit COVID-19 giving a better energy score compared to synthetic drugs. Our data suggest these results encourage further in vitro and in vivo investigations and also encourage traditional use of Kabasura kudineer preventively.

\section{DATA AVAILABILITY STATEMENT}

The original contributions presented in the study are included in the article/Supplementary Materials, further inquiries can be directed to the corresponding author/s.

\section{REFERENCES}

Al-Snafi, A. E. (2016). A review on Cyperus rotundus A potential medicinal plant. IOSR J. Pharm. 6, 32-48. doi: 10.9790/3013-06723248

Amir, M., Khan, A., Mujeeb, M., Ahmad, A., Usmani, S., and Akhtar, M. (2011). Phytochemical analysis and in vitro antioxidant activity of Zingiber officinale. Free Rad. Antioxidants 1, 75-81. doi: 10.5530/ax.2011.4.12

Arumugam, G., Swamy, M. K., and Sinniah, U. R. (2016). Plectranthus amboinicus (Lour.) Spreng: botanical, phytochemical, pharmacological and nutritional significance. Molecules 21:369. doi: 10.3390/molecules21040369

Ashwini, R., Gajalakshmi, S., Mythili, S., and Sathiavelu, A. (2011). Terminalia chebula-a pharmacological review. J. Pharm. Res. 4, 2884-2887.

Aziz, N., Kim, M. Y., and Cho, J. Y. (2018). Anti-inflammatory effects of luteolin: a review of in vitro, in vivo, and in silico studies. J. Ethnopharmacol. 225, 342-358. doi: 10.1016/j.jep.2018.05.019

Batiha, G. E. S., Alkazmi, L. M., Wasef, L. G., Beshbishy, A. M., Nadwa, E. H., and Rashwan, E. K. (2020). Syzygium aromaticum L. (Myrtaceae): traditional uses, bioactive chemical constituents, pharmacological and toxicological activities. Biomolecules 10:202. doi: 10.3390/biom10020202

Bharati, B. D., Sharma, P. K., Kumar, N., Dudhe, R., and Bansal, V. (2011). Pharmacological activity of Andrographis paniculata: a brief review. Pharmacol. Online 2:10.

Buck, T., Arnold, M., Chazan, G., and Cookson, C. (2020). Coronavirus Declared a Pandemic as Fears of Economic Crisis Mount. Available online at: https://www. ft.com/content/d72f1e54-6396-11ea-b3f3-fe4680ea68b5 (accessed March 19, 2020).

Caly, L., Druce, J. D., Catton, M. G., Jans, D. A., and Wagstaff, K. M. (2020). The FDA-approved drug ivermectin inhibits the replication of SARS-CoV-2 in vitro. Antiviral Res. 178:104787. doi: 10.1016/j.antiviral.2020.104787

Cao, B., Wang, Y., Wen, D., Liu, W., Wang, J., Fan, G., et al. (2020). A trial of lopinavir-ritonavir in adults hospitalized with severe Covid-19. N. Engl. J. Med. 382, 1787-1799. doi: 10.1056/NEJMoa2001282

Chang, K. O., Kim, Y., Lovell, S., Rathnayake, A. D., and Groutas, W. C. (2019). Antiviral drug discovery: norovirus proteases and development of inhibitors. Viruses 11:197. doi: 10.3390/v11020197

Cinatl, J., Morgenstern, B., Bauer, G., Chandra, P., Rabenau, H., and Doerr, H. W. (2003). Glycyrrhizin, an active component of liquorice roots, and replication of SARS-associated coronavirus. Lancet 361, 2045-2046. doi: 10.1016/S0140-6736(03)13615-X

Dhara, A. K., Suba, V., Sen, T., Pal, S., and Chaudhuri, A. N. (2000). Preliminary studies on the anti-inflammatory and analgesic activity of the methanolic fraction of the root extract of Tragia involucrata Linn. J. Ethnopharmacol. 72, 265-268. doi: 10.1016/S0378-8741(00)00166-5

\section{AUTHOR CONTRIBUTIONS}

SV and MD conceived and designed the study. SV, MD, SA, and MS carried out the coordination of the study. All authors participated during manuscript development, read, and approved the final version manuscript.

\section{ACKNOWLEDGMENTS}

The authors thank Loyola college, Chennai, India and Sejong University, South Korea for their support.

\section{SUPPLEMENTARY MATERIAL}

The Supplementary Material for this article can be found online at: https://www.frontiersin.org/articles/10.3389/fmolb. 2020.613401/full\#supplementary-material

Dwivedi, V. D., Tripathi, I. P., Bharadwaj, S., Kaushik, A. C., and Mishra, S. K. (2016). Identification of new potent inhibitors of dengue virus NS3 protease from traditional Chinese medicine database. Virusdisease 27, 220-225. doi: 10.1007/s13337-016-0328-6

Elfiky, A. A. (2020). Anti-HCV, nucleotide inhibitor, repurposed against COVID19. Life Sci. 248:117477. doi: 10.1016/j.lfs.2020.117477

Elfiky, A. A., Mahdy, S. M., and Elshemey, W. M. (2017). Quantitative structureactivity relationship and molecular docking revealed a potency of anti-hepatitis C virus drugs against human corona viruses. J. Med. Virol. 89, 1040-1047. doi: 10.1002/jmv.24736

Gangwar, A. K., and Ghosh, A. K. (2014). Medicinal uses and pharmacological activity of Adhatoda vasica. Int. J. Herbal Med. 2, 88-91.

Gautret, P., Lagier, J. C., Parola, P., Meddeb, L., Mailhe, M., Doudier, B., et al. (2020). Hydroxychloroquine and azithromycin as a treatment of COVID-19: results of an open-label non-randomized clinical trial. Int. J. Anti-Micro. Agents 56:105949. doi: 10.1016/j.ijantimicag.2020.105949

Gobalakrishnan, R., Kulandaivelu, M., Bhuvaneswari, R., Kandavel, D., and Kannan, L. (2013). Screening of wild plant species for antibacterial activity and phytochemical analysis of Tragia involucrata L. J. Pharmaceut. Anal. 3, 460-465. doi: 10.1016/j.jpha.2013.07.001

Green, D. V., and Segall, M. (2014). Chemoinformatics in lead optimization. Chemoinformatics Drug Discov. 8, 149-178. doi: 10.1002/9781118742785.ch8

Gupta, R., and Sharma, V. (2011). Ameliorative effects of Tinospora cordifolia root extract on histopathological and biochemical changes induced by aflatoxin-B1 in mice kidney. Toxicol. Int. 18, 94-98. doi: 10.4103/0971-6580.84259

Hossain, M. D., Urbi, Z., Sule, A., and Rahman, K. M. (2014). Andrographis paniculata (Burm. f.) Wall. ex Nees: a review of ethnobotany, phytochemistry, and pharmacology. Sci. World J. 2014:274905. doi: 10.1155/2014/274905

Huang, C., Wang, Y., Li, X., Ren, L., Zhao, J., Hu, Y., et al. (2020). Clinical features of patients infected with 2019 novel coronavirus in Wuhan, China. Lancet 395, 497-506. doi: 10.1016/S0140-6736(20)30183-5

Hussain, M. S., Fareed, S., and Ali, M. (2010). Hygrophila auriculata (K. Schum) Heine: ethnobotany, phytochemistry and pharmacology. Asian J. Traditional Med. 5, 122-131.

Jain, J., Kumar, A., Narayanan, V., Ramaswamy, R. S., Sathiyarajeswaran, P., Devi, M. S., et al. (2020). Antiviral activity of ethanolic extract of Nilavembu Kudineer against dengue and chikungunya virus through in vitro evaluation. J. Ayurveda Integrat. Med. 11, 329-335 doi: 10.1016/j.jaim.2018.05.006

Jasso-Miranda, C., Herrera-Camacho, I., Flores-Mendoza, L. K., Dominguez, F., Vallejo-Ruiz, V., Sanchez-Burgos, G., et al. (2019). Antiviral and immunomodulatory effects of polyphenols on macrophages infected with dengue virus serotypes 2 and 3 enhanced or not with antibodies. Infect. Drug Resist. 12:1833. doi: 10.2147/IDR.S210890 
Jimoh, S. O., Arowolo, L. A., and Alabi, K. A. (2017). Phytochemical screening and antimicrobial evaluation of Syzygium aromaticum extract and essential oil. Int. J. Current Microbiol. Appl. Sci. 6, 4557-4567. doi: 10.20546/ijcmas.2017.607.476

Jindal, A., Kumar, P., and Singh, G. (2012). Extraction and pharmacological evaluation of flavonoids of sida acuta Burmf. Int. J. Green Pharm. 6, 208-211. doi: $10.4103 / 0973-8258.104933$

Jo, S., Kim, S., Shin, D. H., and Kim, M. S. (2020). Inhibition of SARS-CoV 3CL protease by flavonoids. J. Enzyme Inhib. Med. Chem. 35, 145-151. doi: 10.1080/14756366.2019.1690480

Karou, S. D., Nadembega, W. M., Ilboudo, D. P., Ouermi, D., Gbeassor, M., de Souza, C., et al. (2017). Sida acuta Burm. f:: a medicinal plant with numerous potencies. Afr. J. Biotechnol. 6, 2953-2959. doi: 10.5897/AJB2007.000-2463

Kaur, K., and Kaushal, S. (2019). Phytochemistry and pharmacological aspects of Syzygium aromaticum: a review. J. Pharmacogn. Phytochem. 8, 398-406.

Kaushik, S., Jangra, G., Kundu, V., and Yadav, J. P. (2020). Anti-viral activity of Zingiber officinale (Ginger) ingredients against the Chikungunya virus. Virusdisease 31, 270-276. doi: 10.1007/s13337-020-00584-0

Kubica, P., Szopa, A., and Ekiert, H. (2017). Production of verbascoside and phenolic acids in biomass of Verbena officinalis $L$. (vervain) cultured under different in vitro conditions. Nat. Prod. Res. 31, 1663-1668. doi: $10.1080 / 14786419.2017 .1286477$

Kumar, M., Dandapat, S., Kumar, A., and Sinha, M. P. (2014). Pharmacological screening of leaf extract of Adhatoda vasica for therapeutic efficacy. Glob. J. Pharmacol. 8, 494-500.

Kumar, R. A., Sridevi, K., Kumar, N. V., Nanduri, S., and Rajagopal, S. (2004). Anticancer and immunostimulatory compounds from Andrographis paniculata. J. Ethnopharmacol. 92, 291-295. doi: 10.1016/j.jep.2004.03.004

Kumar, S., Kamboj, J., and Sharma, S. (2011). Overview for various aspects of the health benefits of Piper longum linn. fruit. J. Acupunct. Merid. Stud. 4, 134-140. doi: 10.1016/S2005-2901(11)60020-4

Laurie, A. T. R., and Jackson, R. M. (2005). Q-site finder: an energy-based method for the prediction of protein-ligand binding sites. Bioinformatics 21, 1908-1916. doi: 10.1093/bioinformatics/bti315

Leach, A. (2001). Molecular Modelling: Principles and Applications. 2nd ed. Prentice Hall, NJ: Pearson Education Limited.

Li, P., Du, R., Wang, Y., Hou, X., Wang, L., Zhao, X., et al. (2020). Identification of chebulinic acid and chebulagic acid as novel influenza viral neuraminidase inhibitors. Front. Microbiol. 11:182. doi: 10.3389/fmicb.2020.00182

Lin, L. T., Chen, T. Y., Lin, S. C., Chung, C. Y., Lin, T. C., Wang, G. H., et al. (2013). Broad-spectrum antiviral activity of chebulagic acid and punicalagin against viruses that use glycosaminoglycans for entry. BMC Microbiol. 13:187. doi: 10.1186/1471-2180-13-187

Liu, X., and Wang, X. J. (2020). Potential inhibitors against 2019-nCoV coronavirus M protease from clinically approved medicines. J. Genet. Genom. 47, 119-121. doi: 10.1016/j.jgg.2020.02.001

Liu, Y. T., Chen, H. W., Lii, C. K., Jhuang, J. H., Huang, C., S., et al. (2020a). A diterpenoid, 14-deoxy-11, 12-didehydroandrographolide, in andrographis paniculata reduces steatohepatitis and liver injury in mice fed a high-fat and high-cholesterol diet. Nutrients 12:523. doi: 10.3390/nu12020523

Liu, Z., Xiao, X., Wei, X., Li, J., Yang, J., Tan, H., et al. (2020b). Composition and divergence of coronavirus spike proteins and host ACE2 receptors predict potential intermediate hosts of SARS-CoV-2. J. Med. Virol. 92, 595-601. doi: $10.1002 / j m v .25726$

Liu, Z. L., He, Q., Chu, S. S., Wang, C. F., Du, S. S., and Deng, Z. W. (2012). Essential oil composition and larvicidal activity of Saussurea lappa roots against the mosquito Aedes albopictus (Diptera: Culicidae). Parasitol. Res. 110, 2125-2130. doi: 10.1007/s00436-012-2923-9

Madhuri, K., Elango, K., and Ponnusankar, S. (2012). Saussurea lappa (Kuth root): review of its traditional uses, phytochemistry and pharmacology. Orient. Pharmacy Exp. Med. 12, 1-9. doi: 10.1007/s13596-011-0043-1

Mahajan, H., Singh Arora, D., Singh, H., Jain, S. K., Namarta, K., and Singh, J. (2019). Scientific validation of the antimicrobial and antiproliferative potential of Clerodendrum serratum (L.) moon, its phytoconstituents and their biosafety by acute oral toxicity study. Drug Chem. Toxicol. 1, 1-11. doi: 10.1080/01480545.2019.1643875

Mair, C. E., Liu, R., Atanasov, A. G., Schmidtke, M., Dirsch, V. M., and Rollinger, J. M. (2016). Antiviral and anti-proliferative in vitro activities of piperamides from black pepper. Planta Med. 82:P807. doi: 10.1055/s-0036-1596830
Marrelli, M., Menichini, F., and Conforti, F. (2015). A comparative study of Zingiber officinale Roscoe pulp and peel: phytochemical composition and evaluation of antitumour activity. Nat. Prod. Res. 29, 2045-2049. doi: 10.1080/14786419.2015.1020491

Mileva, M., Nikolova, I., Nikolova, N., Mukova, L., Georgieva, A., Dobreva, A., et al. (2015). Investigation of antioxidant and antiviral properties of geraniol. Acta Microbiol. Bulgarica. 31, 48-53.

Mothana, R. A., Abdo, S. A., Hasson, S., Althawab, F., Alaghbari, S. A., and Lindequist, U. (2010). Antimicrobial, antioxidant and cytotoxic activities and phytochemical screening of some yemeni medicinal plants. Evid. Based Complement Alternat. Med. 7, 323-330. doi: 10.1093/ecam/nen004

Muralidharan, N., Sakthivel, R., Velmurugan, D., and Gromiha, M. M. (2020). Computational studies of drug repurposing and synergism of lopinavir, oseltamivir and ritonavir binding with SARS-CoV-2 Protease against COVID19. J. Biomol. Struct. Dyn. 1, 1-7. doi: 10.1080/07391102.2020.1752802

Noreen, R., Intisar, A., Ghaffar, A., Jabeen, F., Abid, M. A., Din, M. I., et al. (2018). Constituents of volatile oil from bark of Clerodendrum serratum (L.) and its antibacterial activity. J. Essential Oil-Bear. Plants 21, 198-205. doi: 10.1080/0972060X.2018.1449669

Ortega, J. T., Suárez, A. I., Serrano, M. L., Baptista, J., Pujol, F. H., and Rangel, H. R. (2017). The role of the glycosyl moiety of myricetin derivatives in anti-HIV-1 activity in vitro. AIDS Res. Ther. 14:57. doi: 10.1186/s12981-017-0183-6

Ouyang, M. A., Wein, Y. S., Zhang, Z. K., and Kuo, Y. H. (2007). Inhibitory activity against tobacco mosaic virus (TMV) replication of pinoresinol and syringaresinol lignans and their glycosides from the root of Rhus javanica var. roxburghiana. J. Agri. Food Chem. 55, 6460-6465. doi: 10.1021/jf0709808

Park, S., Kim, J. I., Lee, I., Lee, S., Hwang, M. W., Bae, J. Y., et al. (2013). Aronia melanocarpa and its components demonstrate antiviral activity against influenza viruses. Biochem. Biophys. Res. Commun. 440, 14-19. doi: 10.1016/j.bbrc.2013.08.090

Patel, J. J., Acharya, S. R., and Acharya, N. S. (2014). Clerodendrum serratum (L.) moon-a review on traditional uses, phytochemistry and pharmacological activities. J. Ethnopharmacol. 154, 268-285. doi: 10.1016/j.jep.2014.03.071

Patel, S. S., Shah, R. S., and Goyal, R. K. (2009). Antihyperglycemic, antihyperlipidemic and antioxidant effects of Dihar, a polyherbal ayurvedic formulation in streptozotocin induced diabetic rats. Indian J. Exp. Biol. $47,564-570$.

Peerzada, A. M., Ali, H. H., Naeem, M., Latif, M., Bukhari, A. H., and Tanveer, A. (2015). Cyperus rotundus L.: Traditional uses, phytochemistry, and pharmacological activities. J. Ethnopharmacol. 174, 540-560. doi: 10.1016/j.jep.2015.08.012

Pelle, M. T., and Callen, J. P. (2002). Adverse cutaneous reactions to hydroxychloroquine are more common in patients with dermatomyositis than in patients with cutaneous Lupus erythematosus. Arch. Dermatol. 138, 1231-1233. doi: 10.1001/archderm.138.9.1231

Pillai, P. G., Suresh, P., Aggarwal, G., Doshi, G., and Bhatia, V. (2011). Pharmacognostical standardization and toxicity profile of the methanolic leaf extract of Plectranthus amboinicus (Lour) spreng. J. Appl. Pharmaceut. Sci. $1,76-81$.

Rahmani, A. H. (2014). Active ingredients of ginger as potential candidates in the prevention and treatment of diseases via modulation of biological activities. Int. J. Physiol. Pathophysiol. Pharmacol. 6, 125-136.

Rajantheran, M., Gill, S. S., Muniapan, B., Sillaalee, K., and Manimaran, S. (2014). A critical analysis of siddha tradition in the context of Malaysian Hindu culture. Life Sci. J. 11, 27-32.

Ramana, M. M. V., Ranade, P. B., Betkar, R. R., Nimkar, A. P., Mundhe, B. C., and Bhar, S. (2015). Flavones: potential antidengue targets in silico approach. J. Chem. Pharm. Res. 7, 585-591.

Rao, N. V., Benoy, K., Hemamalini, K., Kumar, S. S., and Satyanarayana, S. (2007). Pharmacological evaluation of root extracts of tragia involucrata. Int. J. Pharmaceut. Sci. Drug Res. 2, 236-244.

Rathinamoorthy, R., and Thilagavathi, G. (2014). Terminalia chebula-review on pharmacological and biochemical studies. Int. J. Pharm. Tech. Res. 6, 97-116.

Rout, G. R. (2006). Identification of Tinospora cordifolia (Willd.) Miers ex Hook F. Thomas and Using RAPD Markers. Z Naturforsch C 61, 118-122. doi: 10.1515/znc-2006-1-221

Rout, O. P., Acharya, R., Mishra, S. K., and Sahoo, R. (2012). Pathorchur (Coleus aromaticus): a review of the medicinal evidence for its phytochemistry 
and pharmacology properties. Int. J. Appl. Biol. Pharmaceut. Technol. 3, 348-355.

Salve, S. D., and Bhuktar, A. S. (2017). Pharmacognosy and phytochemical evaluation of Hygrophila auriculata (Schumach.) heine root. J. Phytopharm. 6, 210-216.

Selles, C., Dib, M. E. A., Djabou, N., Beddou, F., Muselli, A., Tabti, B., et al. (2013). Antimicrobial activity and evolution of the composition of essential oil from Algerian Anacyclus pyrethrum L. through the vegetative cycle. Nat. Prod. Res. 27, 2231-2234. doi: 10.1080/14786419.2013.811409

Sharma, B. K., Klinzing, D. C., and Ramos, J. D. (2015). Modulatory activities of Zingiber officinale roscoe methanol extract on the expression and activity of MMPs and TIMPs on dengue virus infected cells. Asian Pacific J. Tropical Dis. 5, S19-S26. doi: 10.1016/S2222-1808(15)60849-0

Sharma, V., Kaushik, S., Pandit, P., Dhull, D., Yadav, J., and Kaushik, S. (2019). Green synthesis of silver nanoparticles from medicinal plants and evaluation of their antiviral potential against chikungunya virus. Appl. Microbiol. Biotechnol. 103, 881-891. doi: 10.1007/s00253-018-9488-1

Singh, P. T. M., Singh, O., and Singh, B. H. (2011). Adhatoda vasica Nees: phytochemical and pharmacological profile. Nat. Prod. J. 1, 29-39. doi: 10.2174/2210316311101010029

Singh, R., Chahal, K. K., and Singla, N. (2017). Chemical composition and pharmacological activities of Saussurea lappa: a review. J. Pharmacogn. Phytochem. 6, 1298-1308.

Song, X., He, J., Xu, H., Hu, X. P., Wu, X. L., Wu, H. Q., et al. (2016). The antiviral effects of acteoside and the underlying IFN- $\gamma$-inducing action. Food Func. 7, 3017-3030. doi: 10.1039/C6FO00335D

Tailor, R., Elaraoud, I., Good, P., Hope-Ross, M., and Scott, R. A. (2012). A case of severe hydroxychloroquine-induced retinal toxicity in a patient with recent onset of renal: a review of the literature on the use of hydroxychloroquine in renal impairment. Case Rep. Ophthalmol. Med. 2012:182747. doi: 10.1155/2012/182747

Tcheghebe, O. T., Seukep, A. J., and Tatong, F. N. (2017). Ethnomedicinal uses, phytochemical and pharmacological profiles, and toxicity of Sida acuta Burm. F.: a review article. Pharm. Innov. 6:1.

Thayil, S. M., and Thyagarajan, S.P. (2016). Pa-9: a flavonoid extracted from plectranthus amboinicus inhibits HIV-1 protease. Int. J. Pharmacogn. Phytochem. Res. 8, 1020-1024.

Tiwari, P., Nayak, P., Prusty, S. K., and Sahu, P. K. (2018). Phytochemistry and pharmacology of Tinospora cordifolia: a review. Syst. Rev. Pharm. 9, 70-78. doi: 10.5530/srp.2018.1.14

Upadhyay, A., Agrahari, P., and Singh, D. K. (2014). A review on the pharmacological aspects of Terminalia chebula. Int. J. Pharmacol. 10, 289-298. doi: 10.3923/ijp.2014.289.298
Upadhyay, A. K., Kumar, K., Kumar, A., and Mishra, H. S. (2010). Tinospora cordifolia (Willd.) Hook. F. and Thoms (Guduchi)-validation of the Ayurvedic pharmacology through experimental and clinical studies. Int. J. Ayurveda Res. 1, 112-121. doi: 10.4103/0974-7788.64405

Usmani, A., Khushtar, M., Arif, M., Siddiqui, M. A., Sing, S. P., and Mujahid, M. (2016). Pharmacognostic and phytopharmacology study of Anacyclus pyrethrum: an insight. J. Appl. Pharmaceut. Sci. 6, 144-150. doi: 10.7324/JAPS.2016.60325

Velavan, T. P., and Meyer, C. G. (2020). The COVID-19 epidemic. Trop. Med. Int. Health 25, 278-280. doi: 10.1111/tmi.13383

Wang, H., He, S., Deng, W., Zhang, Y., Li, G., Sun, J., et al. (2020). Comprehensive insights into the catalytic mechanism of middle east respiratory syndrome 3Clike protease and severe acute respiratory syndrome $3 \mathrm{C}$-like protease. ACS Catal. 10, 5871-5890. doi: 10.1021/acscatal.0c00110

Wiart, C., Kumar, K., Yusof, M. Y., Hamimah, H., Fauzi, Z. M., and Sulaiman, M. (2005). Antiviral properties of ent-labdene diterpenes of Andrographis paniculata Nees, inhibitors of herpes simplex virus type 1. Phytother. Res. 19, 1069-1070. doi: 10.1002/ptr.1765

Yang, J. M., and Chen, C. C. (2004). GEMDOCK: a generic evolutionary method for molecular docking. Proteins 55, 288-304. doi: 10.1002/prot.20035

Zakaryan, H., Arabyan, E., Oo, A., and Zandi, K. (2017). Flavonoids: promising natural compounds against viral infections. Arch. Virol. 162, 2539-2551. doi: 10.1007/s00705-017-3417-y

Zandi, K., Teoh, B. T., Sam, S. S., Wong, P. F., Mustafa, M. R., and AbuBakar, S. (2011). In vitro antiviral activity of fisetin, rutin and naringenin against dengue virus type-2. J. Med. Plants Res. 5, 5534-5539. doi: 10.1186/1743-422X8-560

Zaveri, M., Khandhar, A., Patel, S., and Patel, A. (2010). Chemistry and pharmacology of Piper longum L. Int. J. Pharmaceut. Sci. Rev. Res. 5, 67-76.

Zysk, K. G. (2009). Some reflections on siddha medicine in Tamil Nadu. Indian J. History Sci. 44, 199-208.

Conflict of Interest: The authors declare that the research was conducted in the absence of any commercial or financial relationships that could be construed as a potential conflict of interest.

Copyright (c) 2020 Vincent, Arokiyaraj, Saravanan and Dhanraj. This is an openaccess article distributed under the terms of the Creative Commons Attribution License (CC BY). The use, distribution or reproduction in other forums is permitted, provided the original author(s) and the copyright owner(s) are credited and that the original publication in this journal is cited, in accordance with accepted academic practice. No use, distribution or reproduction is permitted which does not comply with these terms. 